\title{
The drying temperature and the moisture content at harvest affect the apparent metabolisable energy of two maize varieties in broiler chickens
}

\section{F. Huart , P. Malumba , F. Béra \& Y. Beckers}

To cite this article: F. Huart , P. Malumba , F. Béra \& Y. Beckers (2020): The drying temperature and the moisture content at harvest affect the apparent metabolisable energy of two maize varieties in broiler chickens, British Poultry Science, DOI: 10.1080/00071668.2020.1784847

To link to this article: https://doi.org/10.1080/00071668.2020.1784847

\section{山ll Article views: 37}

Accepted author version posted online: 22

Jun 2020.

Published online: 20 Jul 2020.

Submit your article to this journal $\square$

\begin{abstract}
ب
\end{abstract}
Q View related articles ¿

View Crossmark data 5 


\title{
The drying temperature and the moisture content at harvest affect the apparent metabolisable energy of two maize varieties in broiler chickens
}

\author{
F. Huart ${ }^{a, b}$, P. Malumbac, F. Béra ${ }^{a}$ and Y. Beckers ${ }^{b}$ \\ aGembloux Agro-Bio Tech, Food Engineering Laboratory, University of Liege, Gembloux, Belgium; bembloux Agro-Bio Tech, Precision Livestock \\ and Nutrition, University of Liege, Gembloux, Belgium; 'Gembloux Agro-Bio Tech, Care FoodlsLife, Terra Teaching and Research Center, \\ University of Liège, Gembloux, Belgium
}

\begin{abstract}
1. The grain drying process may affect the feeding value of maize but until now, no general consensus has been reached. This knowledge is essential to manage maize nutritional value in feed and ensure optimal growth performance of broiler chickens.

2. A total of 72 male Ross 308 were used in a complete randomised block design to assess the effect of initial moisture content (MC) at harvest (high or low MC after the appearance of the black layer) and drying temperature $\left(54^{\circ} \mathrm{C}, 90^{\circ} \mathrm{C}\right.$ or $\left.125^{\circ} \mathrm{C}\right)$ on the apparent faecal digestibility and the AMEn value of two maize grain types (flint and flint-dent varieties). Moreover, the relationship between in vitro dry matter digestibility coefficient (IVDMD) and salt-soluble protein (SSP) content of dried maize grain with AMEn was assessed.

3. High drying temperature $\left(125^{\circ} \mathrm{C}\right)$ significantly decreased the AMEn (by $0.41 \mathrm{MJ} / \mathrm{kg}$ ) of the maize. Maize with high-moisture content at harvest had significantly higher AMEn than maize with low moisture content $(0.38 \mathrm{MJ} / \mathrm{kg})$ depending on the variety. Based on the combination of MC at harvest and drying temperature, an AMEn difference of about $0.65 \mathrm{MJ}$ per kg of dry matter was measured during this experiment. The faecal digestibility of starch remained close to $98 \%$ with low variation between the treatments. The decrease in AMEn at high drying temperature was related to the decrease in non-starch organic matter retention $\left(N_{S O M}\right)$. IVDMD and SSP content were not correlated with AMEn of dried maize $\left(R^{2}<0.1\right)$.

4. This study showed that using drying temperature below $90^{\circ} \mathrm{C}$ for maize grain harvested at high $\mathrm{MC}$, just after the black layer development, can enhance its AMEn. The IVDMD and SSP content failed to predict the AMEn of the dried maize, but further research is required to validate the results of this study.
\end{abstract}

ARTICLE HISTORY

Received 5 January 2020

Accepted 4 May 2020

\section{KEYWORDS}

Broilers; maize; drying; metabolisable energy; prediction

\section{Introduction}

Maize is one of the most suitable crops for monogastrics due to its high energy content which is readily available for poultry. However, the nutritional value of maize grain may vary from batch to batch, even between samples with a similar proximate composition and this is likely to affect broiler chickens growth performance (Gehring et al. 2012, 2013; Huart et al. 2018). Among the factors that can influence the nutritional value of maize grain, drying processes have been cited (Cowieson 2005; Gehring et al. 2012, 2013; Kaczmarek et al. 2013; Malumba et al. 2014; Odjo et al. 2016; Li et al. 2017; Huart et al. 2018; Odjo et al. 2018).

Indeed, in many areas throughout the world, maize is harvested at high (22-37\%) moisture content (MC). To ensure optimal conservation, maize grains are artificially dried to reach a final moisture of about $15 \%$. In Belgium, maize grains are commonly dried in a drying tower. The grain flows from the top to the bottom by gravity and heated airflow is applied perpendicular to grain flow. Air temperature is commonly more than $100^{\circ} \mathrm{C}$. The drying temperature, drying time and air velocity will vary according to the initial moisture content of the maize grain, drying tower system and grain flow from the field during harvest period. Drying process may result in loss of maize nutritional value. Several studies have tried to assess the impact of drying temperatures on the nutritional value of maize grain for poultry (Kaczmarek et al. 2013, 2007;
Barrier-Guillot et al. 1993; Bhuiyan et al. 2011; Rivera et al. 1978; Carvalho et al. 2009, 2004). These studies tend to assert that a high drying temperature could affect the metabolisable energy of the maize and consequently broiler performance as maize grain supplies a huge proportion of the total feed energy. However, no general consensus has been reached, probably due to the diversity of the experimental procedures applied (Odjo et al. 2015).

Besides the effect of drying temperature alone, Malumba et al. (2014) showed that structural modifications that occur inside the grain during the drying process may be modulated by the MC at harvest. However, there is a lack of information about the influence of MC at harvest on maize nutrients digestibility during drying. In a review, Odjo et al. (2015) suggested that the impact of the drying process on maize quality is strongly dependent on MC and should be taken into account during experimentation.

Maize grading methods are based on physical attributes which have been shown to be poor estimators of maize nutritional value (Leeson et al. 1993; Dale 1994). Thus, others assays that may account for difference in maize quality have been developed. Métayer et al. (2009) and Gehring et al. (2013) postulated that salt-soluble protein (SSP) could be a useful indicator to distinguish maize with a high nutritional potential. According to Gehring et al. (2013), sources of maize with similar proximate composition may vary in their digestible energy content, and in such a situation, SSP 
may be used to differentiate those with wide-ranging AMEn. Métayer et al. (2009) observed that increasing drying temperatures from $80^{\circ} \mathrm{C}$ to $140^{\circ} \mathrm{C}$ resulted in a reduction of the SSP content and a decrease in AMEn by $0.33 \mathrm{MJ} / \mathrm{kg}$. They concluded that the SSP assay (Promatest) can be a good indicator to predict the nutritional value of dried maize for poultry. This assay may result in an effective method to assess the metabolisable energy of maize samples, but data are limited and more research is still required.

In vitro protocols were developed in past decades to rapidly assess the nutritional value of feedstuffs because in vivo experiments are time consuming and expensive. Recently Huart et al. (2018) tried to correlate in vitro digestion with the in vivo growth performance of broiler chickens fed diets containing maize harvested at two MC and dried at different temperatures. They used a modified three-step in vitro procedure developed by Tervilä-Wilo et al. (1996). This study showed that increasing drying temperature and high $\mathrm{MC}$ at harvest improved in vitro maize dry matter digestibility (IVDMD) but did not improve its AMEn under the conditions of the performed in vivo experiment. However, they were unable to conclude that digestibility differences were only due to the drying process. Indeed, grain drying affected its milling capacity, leading to different particle size distributions. This unexpected consequence probably affected chicken behaviour and, consequently, the composition of ingested feed in the mash diet.

In the present study, the impact of MC at harvest and drying temperature on in vivo digestibility and AMEn of two maize varieties was assessed using tube-fed broilers. A modified in vitro protocol of Tervilä-Wilo et al. (1996) and the Promatest were used to assess their relationship with the metabolisable energy of dried maize grain.

\section{Materials and methods}

\section{Maize grains and drying conditions}

Two Belgian maize cultivars, Zidane (KWS, Einbeck, Germany) and Colisée (KWS, Einbeck, Germany), were used in this study. The two maize varieties were sowed and harvested on the same dates and field grown in the same area. They were chosen because of their contrasting grain phenotypes. According to their respective breeder, the Var I (Zidane) is a flint-dent maize and the Var II (Colisée) is a pure flint maize. Maize grains were harvested just after physiological maturity (appearance of the black layer) at $36.7 \%$ and $34.0 \%$ (wet basis) of MC and $48 \mathrm{~d}$ after physiological maturity at $23.4 \%$ and $24.5 \%$ (wet basis) of MC for Var I and Var II, respectively. Samples were sealed in plastic bags and stored at $-18^{\circ} \mathrm{C}$ until drying.

Each maize from the two dates of harvest was split into three batches. Before drying, the grains were equilibrated at ambient temperature the night before. Approximatively $1.5 \mathrm{~kg}$ of maize sample was dried in the fluidised-bed drier, as described by Janas et al. (2010). A fluidised-bed drier creates homogenous drying conditions. Air temperature, velocity and humidity were measured during the drying process with an accuracy of $0.1^{\circ} \mathrm{C}, 0.2 \mathrm{~m} / \mathrm{s}$ and $0.1 \%$, respectively. The first batch was dried at $54^{\circ} \mathrm{C}$ for $270 \mathrm{~min}$, the second at $90^{\circ} \mathrm{C}$ for $90 \mathrm{~min}$ and the last one at $125^{\circ} \mathrm{C}$ for $40 \mathrm{~min}$. Drying times were chosen to obtain a final moisture below $15 \%$.

\section{Bird management}

The experiment was approved by the Animal Ethics Committee of the University of Liege (Protocol number 14-1703). The animal experiment was a $2 \times 3$ factorial arrangement with three drying temperatures and two MC within six randomised complete blocks. Seventy-two, oneday-old male Ross 308 were used and were initially brooded at a temperature of $32^{\circ} \mathrm{C}$, which was gradually decreased as the chicks increased in age, with a final set point of $24^{\circ} \mathrm{C}$ at 32 $\mathrm{d}$ of age. A $12 \mathrm{~h}$ light-dark schedule was used, as recommended by Teeter et al. (1984). During the first 10 d, chicks were fed with a starter commercial diet (Starter M 70, Leievoeders, Waregem, Belgium). Then, until the age of 35 $\mathrm{d}$ and during rest periods, broiler chickens were fed with the same grower commercial diet (Grower M 711, Leievoeders, Waregem, Belgium). At the age of $26 \mathrm{~d}$, six groups of 12 broiler chickens with similar average body weight were allocated pairwise to 36 cages in each of the six blocks.

The tube-feeding technique was similar to the method of Lessire (1990), with slight modifications. At the age of $35 \mathrm{~d}$, after $16 \mathrm{~h}$ of starvation, broiler chickens were tube fed dried maize. The six treatments were randomly assigned to six cages in each of the six blocks. Thus, a total of 12 chickens (two broilers per cage) were used per treatment. A $60 \mathrm{ml}$ syringe elongated with a $6 \mathrm{~mm}$ plastic tube diameter was used. Maize grains were firstly ground through a $1 \mathrm{~mm}$ aperture screen (Fritsch pulverisette 19, Idar-Oberstein, Germany). This flour was further ground through a $0.5 \mathrm{~mm}$ sieve (Fritch pulverisette 14, IdarOberstein, Germany). The final size reduction allowed a better homogeneity of the mixture and facilitated the passage through the syringe during tube feeding. The ground maize was blended with water (44 $\mathrm{g}$ of flour with $56 \mathrm{~g}$ of water) in a concentration similar to the concentration used by Teeter et al. (1984) and Lessire (1990). The mixture was then introduced into the crop of the chicken. Tube feeding was carried out daily at 8:00 am and 16:00 pm. The amount of feed was recorded and was approximatively equal to $50 \mathrm{~g}$ of dry matter (DM) per broiler per day (i.e. $110 \mathrm{~g}$ of mixture similar to Lessire (1990)). A sample of the mixture was collected before feeding each chicken to determine the exact amount of DM ingested. After $16 \mathrm{~h}$ of starvation from the last feeding $(16: 00 \mathrm{pm})$, excreta from each cage were collected and subsequently frozen. Compared with the study of Lessire (1990), the fasting period was shortened because no more residues were observed in the excreta after $16 \mathrm{~h}$ of starvation. Samples were then freeze-dried and ground for further analyses. Broiler chickens were tube-fed first with the six treatments of the Var I (flint-dent maize). Because of the time-consuming procedure, tube feeding was carried out during two consecutive days at a rate of 18 cages per day. After a rest period of $32 \mathrm{~h}$ during which the chicken had free access to the commercial feed, as advised by Sibbald (1978) to avoid weight loss, a second experiment was carried out in the same conditions with the six treatments of the Var II (flint maize). Water was provided ad libitum throughout the assay period.

\section{In vitro digestion}

The in vitro digestibility coefficient of dry matter (IVDMD) of the maize flour used during animal experimentation was determined in a three-step experiment, according to the method described by Tervilä-Wilo et al. (1996) with slight modifications. To simulate digestion phase in the crop, $1 \mathrm{~g}$ of 
maize flour sample was weighed in a $50 \mathrm{ml}$ polypropylene tube. Sodium acetate $(10 \mathrm{ml} 0.05 \mathrm{M}, \mathrm{pH} 5.4)$ was added into the tubes and tubes were placed in a water bath under gentle agitation for $30 \mathrm{~min}$ at $40^{\circ} \mathrm{C}$. After this step, a chloramphenicol solution $(100 \mu \mathrm{l}, 0.5 \mathrm{~g} / 100 \mathrm{ml}$ of ethanol) and $\mathrm{HCl}$ solution ( $4 \mathrm{ml}$ of $0.2 \mathrm{M}$ ) were added and the $\mathrm{pH}$ was adjusted to $3 \pm 0.2$ with acetic acid $(1 \mathrm{M})$. Fresh pepsin solution $(2 \mathrm{ml}$, $25 \mathrm{~g} / \mathrm{l}$ of $0.05 \mathrm{M} \mathrm{HCl}$ ) prepared from pepsin powder (EC 3.4.23.1; from porcine gastric mucosa; $>250 \mathrm{U} / \mathrm{mg}$ of solid powder, P7000; Sigma-Aldrich, Germany) was then added and the tubes were placed in a water-bath for $45 \mathrm{~min}$ at $40^{\circ} \mathrm{C}$ under gentle agitation, with manual agitation every $15 \mathrm{~min}$. After the gastric phase, $15 \mathrm{ml}$ of sodium monohydrogenocarbonate $0.2 \mathrm{M}$ was added. The $\mathrm{pH}$ was then adjusted to $6.8 \pm 0.2$ using either $0.1 \mathrm{M} \mathrm{HCl}$ or a $0.1 \mathrm{M} \mathrm{NaOH}$ solution. Then, $1 \mathrm{ml}$ of fresh pancreatin solution (prepared from pancreatin, $8 \times$ USP/g of solid powder, P7545; SigmaAldrich, Germany; $100 \mathrm{~g} / \mathrm{l}$ of phosphate buffer $0.2 \mathrm{M}, \mathrm{pH}$ 6.8; undissolved tissue material was removed after centrifugation at $3220 \mathrm{xg}$ ) was added and the tubes were incubated under agitation at the same temperature in the same waterbath for a period of $2 \mathrm{~h}$, with manual agitation every $30 \mathrm{~min}$. Finally, the supernatant and the undigested fraction were separated after centrifugation at $3220 \mathrm{x}$ g during $10 \mathrm{~min}$. The undigested fractions recovered were washed with a $10 \mathrm{ml}$ solution of acetone and ethanol, dried at $60^{\circ} \mathrm{C}$ in order to attain a constant weight $(72 \mathrm{~h})$ and then weighed.

The IVDMD was calculated as follows:

IVDMD $=$ (dry weight of the maize before hydrolysis dry weight of the residue)/dry weight of the maize before hydrolysis

Dry weight of the maize before the hydrolysis is the dry weight of the sample weighed before in vitro digestion. Dry weight of the residue was the dry weight $\left(60^{\circ} \mathrm{C}\right.$ during $\left.72 \mathrm{~h}\right)$ of the sample after hydrolysis.

\section{Chemical analyses}

All analyses were conducted in duplicate. Maize grains and freeze-dried excreta were ground through a $0.5 \mathrm{~mm}$ sieve (Fritch pulverisette 14, Idar-Oberstein, Germany). The DM of maize grains, excreta and mixture samples were determined using AOAC (1990) method 967.03. Ash of maize grains and excreta was determined using AOAC (1990) method 942.05. Flour starch content was quantified by Ewers polarimetric method (ISO 10520:1997). Starch content of excreta was determined using AOAC (1990) 916.11 method with slight modifications. Times of incubation were 10,60 and $120 \mathrm{~min}$ for dimethyl sulphoxide treatment, $\alpha$-amylase digestion and amyloglucosidase digestion, respectively. Protein content was determined by the Dumas method (ISO 16634-1:2008). The Marquardt method (1983) was used in order to quantify uric acid in the excreta samples. Gross energy was measured using an adiabatic bomb calorimeter (1241 Adiabatic Calorimeter, PARR Instrument Co., Illinois, USA). Neutral detergent fibre (NDF) and acid detergent fibre (ADF) were determined using an ANKOM-Fibre Analyser (ANKOM-Technology, Fairport, NY) according to the method of Van Soest et al. (1991). NDF and ADF content were corrected for ash content and NDF was determined for maize using thermostable amylase (Termamyl ${ }^{\circledR}$, Novo Nordisk, Bagsværd, Denmark). Lipid content was determined using a soxhlet extractor
(AOAC 1990, method 920.29). The Promatest procedure (AFNOR (2008), NF V03-741) was used to estimate the SSP content of dried and freeze-dried maize grains according to Odjo et al. (2012). SSP content was determined on a representative sample of the maize flour used during the animal experimentation. Salt-soluble relative concentrations were expressed in terms of $\mathrm{mg}$ of equivalent Bovine Serum Albumin/100 ml of extraction solution (EBSA). Thousand kernels weight (TKW) was assessed on each maize batch as follows; 200 wet kernels were randomly collected from each frozen sample after thawing overnight and weighed. Collection and weighing were conducted three times. TKW was calculated based on mean value corrected for DM content. Vitreousness of the maize was quantified by a manual dissection method (Dombrinkkurtzman and Bietz 1993), as described by Giuberti et al. (2013). The vitreousness was expressed as the weight of vitreous endosperm divided by the weight of total endosperm.

The faecal digestibility coefficients of starch, AME and organic matter retention $\left(\mathrm{OM}_{\mathrm{R}}\right)$ were obtained by calculating the difference between the content of total DM nutrient ingested and excreted. The non-starch organic matter retention $\left(\mathrm{NSOM}_{\mathrm{R}}\right)$ was calculated as follows:

$$
\begin{aligned}
& \mathrm{NSOM}_{\mathrm{R}}(\%)=\left[\left(\mathrm{OM}_{\text {ingested }}-\mathrm{Starch}_{\text {ingested }}\right)-\left(\mathrm{OM}_{\text {excreta }}-\right.\right. \\
& \text { Starch } \left.\left._{\text {excreta }}\right)\right] /\left(\mathrm{OM}_{\text {ingested }}-\text { Starch }_{\text {ingested }}\right) \times 100
\end{aligned}
$$

Where $\mathrm{NSOM}_{\mathrm{R}}$ was the non-starch organic matter retention, $\mathrm{OM}_{\text {ingested }}$ and $\mathrm{OM}_{\text {excreta }}$ the organic matter ingested and excreted, respectively. Starch $\mathrm{ingested}_{\text {and }} \mathrm{starch}_{\text {excreta }}$ were the amount of starch ingested and excreted, respectively.

AME was corrected to zero-nitrogen balance using the following equation (Larbier and Leclercq 1992):

AMEn $(\mathrm{MJ} / \mathrm{kg} \mathrm{DM})=\operatorname{AME}(\mathrm{MJ} / \mathrm{kg} \mathrm{DM})-0.0344(\Delta \mathrm{N}$ (g)/feed ingested ( $\mathrm{kg} \mathrm{DM})$ )

where AME was the metabolisable energy, $\mathrm{N}$ the difference between nitrogen ingested and excreted and 0.0344 was the energy equivalent $(\mathrm{MJ} / \mathrm{kg})$ of uric acid nitrogen.

As uric acid is the major urinary nitrogen $(\mathrm{N})$ compound in poultry excreta, the apparent faecal digestibility coefficient of protein (ADP) was estimated by subtracting the $\mathrm{N}$ of uric acid from total excreta N, as proposed by Rotter et al. (1989):

$$
\begin{array}{r}
\mathrm{ADP} \\
6.25(\mathrm{~g})
\end{array}
$$

where ADP was the apparent faecal digestibility coefficient of protein, $\mathrm{N}_{\text {ingested }}$ the total amount of ingested $\mathrm{N}(\mathrm{g})$ and $\mathrm{N}_{\text {excreta }}$ the total amount of $\mathrm{N}$ in excreta corrected for uric acid content ( $\mathrm{g} N$ of excreta sample $-\mathrm{g} \mathrm{N}$ of uric acid in excreta sample).

\section{Statistical analyses}

Data were analysed by ANOVA using the Proc Mixed procedure of SAS (SAS institute, 9.4). Each cage was considered an experimental unit and cage location served as the blocking factor. Each treatment was represented by six replicate cages with 12 broiler chickens (two broilers per cage). The model included drying temperature, $\mathrm{MC}$ at harvest and the drying temperature $\mathrm{x} \mathrm{MC}$ interaction as the fixed effect with block as the random effect. Body weight of chickens before being force-fed was used as a covariate. The interaction between 
fixed and random effects was not significant and was removed from the model. Normality and equal variance of the error terms in the linear models were checked by inspection of residual plots. Two outliers were detected using the univariate procedure of SAS and removed from the data for starch digestibility of Var II, whereby the outliers were removed from broilers fed with Var II dried at $125^{\circ} \mathrm{C}$ and harvest at $34 \%$ and $24.5 \%$ of MC. Data are expressed as least squares means. When interactions were significant $(\mathrm{P}<0.05)$, the Tukey-Kramer method was used to detect the differences between individual treatment means. Effects were considered to be significant when $\mathrm{P}<0.05$. The Pearson's correlations between variables were determined using the corr procedure of SAS.

\section{Results}

Table 1 shows the chemical composition of freeze-dried maize grains. For similar maturity stages, the harvesting $\mathrm{MC}$ of Var I was $8 \%$ higher than Var II at maturity, but $5 \%$ lower 48 d later (post-maturity stage). Starch content of Var I increased during the post-maturation stage, while the starch content of the Var II decreased at the same time. For both varieties, there was a slight increase in protein and NDF content between the first and the second date of harvest while lipid content decreased between 13\% and 17\% (Table 1). TKW, gross energy, ash and ADF didn't vary according to the harvesting time. Endosperm hardness did not change for Var I, while results showed that, even after the emergence of the black layer, vitreousness of Var II slightly decreased from $83.9 \%$ to $79.3 \%$.

Var I contained more crude protein but less SSP than Var II. The vitreousness of Var II was higher at maturity but lower at post-maturity stage than Var I (Table 1).

The chemical composition of dried maize used for animal experimentation (starch, protein, gross energy and ash) is shown in Table 2. Maize dried at different temperatures but from the same batch had approximatively the same composition. The starch content of dried maize was slightly higher than that of freeze-dried maize (Table 1) for Var I (4.4\%) harvested at maturity $(367 \mathrm{~g} / \mathrm{kg})$ and for Var II (3\%) harvested after maturity $(245 \mathrm{~g} / \mathrm{kg})$.

The effect of maize harvest $\mathrm{MC}$ and drying temperature on faecal starch digestibility, ADP, $\mathrm{OM}_{\mathrm{R}}, \mathrm{NSOM}_{\mathrm{R}}$ and AMEn of
Var I and II are presented in Tables 3 and 4, respectively. The $\mathrm{MC}$ at harvest did not affect faecal starch digestibility, but increasing the drying temperature from $54^{\circ} \mathrm{C}$ to $125^{\circ} \mathrm{C}$ significantly decreased faecal starch digestibility for both maize varieties. A significant interaction between factors revealed that, at high MC, the faecal starch digestibility coefficient for Var I decreased above $90^{\circ} \mathrm{C}(0.989$ vs. 0.973$)$ while its faecal starch digestibility coefficient was significantly lowered when processed at $54^{\circ} \mathrm{C}$ at low MC (0.988 vs. 0.976). For Var II at high $\mathrm{MC}$, faecal starch digestibility remained constant, but decreased at low MC (0.992 vs. 0.978) with increasing drying temperature resulting in a significant interaction.

No significant interactions were observed between MC and drying temperature for $\mathrm{ADP}, \mathrm{OM}_{\mathrm{R}}$ and $\mathrm{NSOM}_{\mathrm{R}}$. ADP, $\mathrm{OM}_{\mathrm{R}}$ and $\mathrm{NSOM}_{\mathrm{R}}$ were not significantly influenced by initial MC. However, despite this non-significant effect, high MC at harvest reduced the ADP of Var II (0.670 vs. 0.643) and improved its $\mathrm{NSOM}_{\mathrm{R}}(44 \%$ vs. $41.9 \%)$. Drying temperature significantly affected $\mathrm{ADP}, \mathrm{OM}_{\mathrm{R}}$ and $\mathrm{NSOM}_{\mathrm{R}}$ of Var I. There was a slight increase in $\mathrm{ADP}$ and $\mathrm{NSOM}_{\mathrm{R}}$ with increasing drying temperature from $54^{\circ} \mathrm{C}$ to $90^{\circ} \mathrm{C}$, while, at $125^{\circ} \mathrm{C}, \mathrm{ADP}$ and $\mathrm{NSOM}_{\mathrm{R}}$ clearly decreased (5.4 points and 6.9 points, respectively) as did $\mathrm{OM}_{\mathrm{R}}$ (2.2 points). These effects were more pronounced at high $\mathrm{MC}$, even if no significant interaction was observed. For Var II, no significant changes of $\mathrm{ADP}, \mathrm{OM}_{\mathrm{R}}$ and $\mathrm{NSOM}_{\mathrm{R}}$ were observed. The ADP, $\mathrm{OM}_{\mathrm{R}}$ and $\mathrm{NSOM}_{\mathrm{R}}$ of Var I were, on average, 5, 1 and 7 points higher than Var II, respectively.

No significant interactions were observed between drying temperature and MC for AMEn of both varieties (Tables 3 and 4). Statistically, high MC at harvest (34\%) led to better AMEn $(0.38 \mathrm{MJ} / \mathrm{kg})$ for Var II compared with maize harvest at low MC (Table 4). The AMEn of the Var I was higher at high $\mathrm{MC}$ until $90^{\circ} \mathrm{C}$, even if no statistical difference was observed (Table 3). Drying maize at $125^{\circ} \mathrm{C}$ significantly reduced the AMEn by 0.41 and $0.29 \mathrm{MJ} / \mathrm{kg}$ for Var I and Var II, respectively. The decrease in AMEn with increasing drying temperature was mostly observed above $90^{\circ} \mathrm{C}$ (Tables 3 and 4). The average AMEn of Var I was similar to the AMEn of Var II.

In order to assess the relationship between in vivo digestibilities, Pearson's correlations were performed (Table 5 for Var I and Table 6 for Var II). The faecal digestibility of starch, $\mathrm{ADP}, \mathrm{OM}_{\mathrm{R}}$ and $\mathrm{NSOM}_{\mathrm{R}}$ was positively and significantly correlated with AMEn for both varieties assessed.

Table 1. Chemical composition of freeze-dried maize grains ${ }^{1}$

\begin{tabular}{|c|c|c|c|c|}
\hline \multirow[b]{2}{*}{ Time of harvest } & \multicolumn{2}{|c|}{ Var I (Flint-dent maize) } & \multicolumn{2}{|c|}{ Var II (Flint maize) } \\
\hline & Maturity & $48 \mathrm{~d}$ after maize maturity & Maturity & $48 \mathrm{~d}$ after maize maturity \\
\hline Moisture content $\left(\mathrm{g} / \mathrm{kg} \mathrm{FM}^{2}\right)$ & 367 & 234 & 340 & 245 \\
\hline Starch content $(\mathrm{g} / \mathrm{kg})$ & 692 & 719 & 730 & 712 \\
\hline Protein content $(\mathrm{g} / \mathrm{kg})$ & 91.6 & 94.1 & 81.9 & 85.3 \\
\hline $\mathrm{SSP}^{3}$ content $\left(\mathrm{EBSA}^{4}\right)$ & 48.7 & 43.5 & 55.6 & 54.6 \\
\hline Lipid $(\mathrm{g} / \mathrm{kg})$ & 54.0 & 45.2 & 52.9 & 46.1 \\
\hline $\operatorname{NDF}^{5}(\mathrm{~g} / \mathrm{kg})$ & 66.7 & 70.6 & 64.2 & 66.3 \\
\hline $\mathrm{ADF}^{6}(\mathrm{~g} / \mathrm{kg})$ & 27.3 & 24.5 & 21.2 & 20.6 \\
\hline Ash $(\mathrm{g} / \mathrm{kg})$ & 16.4 & 17.8 & 16.0 & 15.4 \\
\hline Gross Energy (MJ/kg DM) & 19.1 & 19.1 & 19.1 & 19.1 \\
\hline TKW $(\mathrm{g} / \mathrm{kg})$ & 323 & 338 & 329 & 332 \\
\hline Vitreousness (\%) & 81.0 & 81.3 & 83.9 & 79.3 \\
\hline
\end{tabular}

${ }^{1}$ Analyses were performed on duplicate samples except for thousand kernel weight (TKW) performed on triplicate and vitreousness performed on 10 kernels.

${ }^{2}$ Fresh matter

${ }^{3}$ Salt-soluble protein

${ }^{4}$ Equivalent bovine serum albumin

${ }^{5}$ Neutral detergent fibre

${ }^{6}$ Acid detergent fibre 
Table 2. Chemical composition of fluidised bed dried maize grain used during the animal experimentation ${ }^{1}$

\begin{tabular}{|c|c|c|c|c|c|c|}
\hline Variety & Moisture content at harvest & Drying temperature & Starch (g/kg DM) & Protein (g/kg DM) & Gross Energy (MJ/kg DM) & Ash (g/kg DM) \\
\hline \multirow{5}{*}{ Var I (flint-dent maize) } & $36.7 \%$ & $54^{\circ} \mathrm{C}$ & 722 & 92.9 & 19.3 & 16.1 \\
\hline & & $90^{\circ} \mathrm{C}$ & 717 & 94.8 & 19.2 & 18.2 \\
\hline & & $125^{\circ} \mathrm{C}$ & 728 & 92.7 & 19.2 & 19.5 \\
\hline & & $90^{\circ} \mathrm{C}$ & 709 & 95.1 & 19.2 & 18.0 \\
\hline & & $125^{\circ} \mathrm{C}$ & 716 & 94.6 & 19.1 & 17.2 \\
\hline \multirow[t]{6}{*}{ Var II (flint maize) } & $34.0 \%$ & $54^{\circ} \mathrm{C}$ & 727 & 84.3 & 19.4 & 16.8 \\
\hline & & $90^{\circ} \mathrm{C}$ & 722 & 84.6 & 19.5 & 16.4 \\
\hline & & $125^{\circ} \mathrm{C}$ & 725 & 83.6 & 19.2 & 15.6 \\
\hline & $24.5 \%$ & $54^{\circ} \mathrm{C}$ & 738 & 87.1 & 18.9 & 18.9 \\
\hline & & $90^{\circ} \mathrm{C}$ & 737 & 87.2 & 19.0 & 17.0 \\
\hline & & $125^{\circ} \mathrm{C}$ & 728 & 85.8 & 19.0 & 16.4 \\
\hline
\end{tabular}

${ }^{1}$ Analyses were performed on duplicate samples. Values expressed on a dry matter basis.

A high correlation was found between AMEn and $\mathrm{OM}_{\mathrm{R}}$ (0.956 for Var I and 0.864 for Var II). AMEn was highly correlated with $\mathrm{NSOM}_{\mathrm{R}}$ (0.917 for Var I and 0.714 for Var II). ADP and $\mathrm{NSOM}_{\mathrm{R}}$ were highly significantly correlated with $\mathrm{OM}_{\mathrm{R}}$ (Tables 5 and 6). Finally, a significant correlation was observed between ADP and $\mathrm{NSOM}_{\mathrm{R}}(0.909$ and 0.689 for Var I and II, respectively). Coefficients of correlation in all cases were higher for Var I.

The Figure shows that the drying temperatures and initial MC of grains affected the IVDMD of maize varieties and their SSP content in the same way. At high MC, IVDMD increased almost linearly with increasing drying temperature, while at lower MC its improvement was only observed above $90^{\circ} \mathrm{C}$. Except for the temperature of $54^{\circ} \mathrm{C}$, higher MC led to a better IVDMD (by 5-7 points). The SSP content of maize harvested at low $\mathrm{MC}$ was higher than maize harvested at high MC (12-14 EBSA), except at $125^{\circ} \mathrm{C}$. The SSP content of both varieties harvested at low MC decreased linearly with increasing drying temperature from $54^{\circ} \mathrm{C}$ to $125^{\circ} \mathrm{C}$ (Figure 1b). At high $\mathrm{MC}$, a non-linear reduction of SSP was observed with increasing drying temperature from $54^{\circ} \mathrm{C}$ to $125^{\circ} \mathrm{C}$ due to a lower reduction of its value between $90^{\circ} \mathrm{C}$ and $125^{\circ} \mathrm{C}$.

\section{Discussion}

Maize grains were harvested between $34 \%$ and 36\% MC when the black layer developed in the grain. According to Marton et al. (2007), after black layer development, only water content can progress and MC decreases until it reaches an equilibrium, which depends on meteorological conditions. The constant TKW observed after black layer appearance showed that this was a reliable tool to assess the achievement of maximum DM accumulation in maize. However, there were still some modifications occurring in the proximate composition of grain, as attested by the slight variations in starch, protein and SSP during the postmaturity stage (Table 1). Huart et al. (2018) and Ajayi et al. (2005) observed that even when assimilates are no longer being imported into the seeds from the plant, significant physiological and compositional changes still occur within the seed. However, it is still not known how these reorganisations occur inside the kernel.

Maize used in Europe are mainly of the flint variety but proportions of soft and corneous endosperm may vary according to the variety (Brown et al. 1985). Despite their supposed dissimilarity of kernel hardness, the vitreousness of varieties used in this study was very similar. According to Gehring et al. (2013), variability is typically low within

Table 3. Effect of drying temperature and moisture content at harvest on faecal starch digestibility coefficient, apparent faecal digestibility coefficient of protein, organic matter and non-starch organic matter retention and the apparent metabolisable energy corrected for a zero-nitrogen balance of Var I $(n=6)^{1}$.

\begin{tabular}{|c|c|c|c|c|c|c|}
\hline \multirow[b]{2}{*}{$\begin{array}{l}\text { Moisture } \\
\text { content }\end{array}$} & \multirow[b]{2}{*}{$\begin{array}{c}\text { Drying } \\
\text { temperature }\end{array}$} & \multirow[b]{2}{*}{$\begin{array}{c}\text { Faecal digestibility coefficient } \\
\text { Starch }\end{array}$} & \multirow[b]{2}{*}{$\begin{array}{c}\text { Apparent faecal digestibility coefficient of } \\
\text { Protein }\end{array}$} & \multicolumn{2}{|c|}{ Retention } & \multirow[b]{2}{*}{$\begin{array}{l}\text { AMEn (MJ } / \mathrm{kg} \\
\text { DM) }\end{array}$} \\
\hline & & & & $\begin{array}{l}\mathrm{OM}^{2} \\
(\%)\end{array}$ & $\begin{array}{l}\mathrm{NSOM}^{3} \\
(\%)\end{array}$ & \\
\hline \multirow[t]{3}{*}{$36.7 \%$} & $54^{\circ} \mathrm{C}$ & $0.989^{\mathrm{a}}$ & 0.726 & 86.8 & 53.3 & 16.4 \\
\hline & $90^{\circ} \mathrm{C}$ & $0.986^{\mathrm{a}}$ & 0.738 & 86.1 & 52.0 & 16.2 \\
\hline & $125^{\circ} \mathrm{C}$ & $0.973^{\mathrm{b}}$ & 0.652 & 83.4 & 43.5 & 15.8 \\
\hline \multirow[t]{3}{*}{$23.4 \%$} & $54^{\circ} \mathrm{C}$ & $0.988^{\mathrm{a}}$ & 0.701 & 85.6 & 49.8 & 16.0 \\
\hline & $90^{\circ} \mathrm{C}$ & $0.976^{\mathrm{b}}$ & 0.734 & 85.4 & 53.9 & 16.1 \\
\hline & $125^{\circ} \mathrm{C}$ & $0.978^{\mathrm{b}}$ & 0.711 & 84.5 & 48.7 & 15.8 \\
\hline SEM & & 0.0023 & 0.0201 & 0.78 & 2.62 & 0.14 \\
\hline \multirow{2}{*}{\multicolumn{7}{|c|}{$\begin{array}{l}\text { Main effects } \\
\text { Moisture content }\end{array}$}} \\
\hline & & & & & & \\
\hline \multicolumn{2}{|c|}{$36.7 \%$} & 0.983 & 0.705 & 85.4 & 49.6 & 16.1 \\
\hline \multicolumn{2}{|c|}{$23.4 \%$} & 0.981 & 0.715 & 85.2 & 50.8 & 16.0 \\
\hline \multicolumn{7}{|c|}{ Drying temperature } \\
\hline \multicolumn{2}{|c|}{$54^{\circ} \mathrm{C}$} & 0.989 & $0.713^{\mathrm{ab}}$ & $86.2^{\mathrm{a}}$ & $51.6^{\mathrm{a}}$ & $16.2^{\mathrm{a}}$ \\
\hline \multicolumn{2}{|l|}{$90^{\circ} \mathrm{C}$} & 0.981 & $0.736^{\mathrm{a}}$ & $85.8^{\mathrm{a}}$ & $53.0^{\mathrm{a}}$ & $16.2^{\mathrm{a}}$ \\
\hline \multicolumn{2}{|l|}{$125^{\circ} \mathrm{C}$} & 0.976 & $0.682^{\mathrm{b}}$ & $84.0^{\mathrm{b}}$ & $46.1^{\mathrm{b}}$ & $15.8^{\mathrm{b}}$ \\
\hline \multicolumn{7}{|c|}{ P-value } \\
\hline \multicolumn{2}{|c|}{ Moisture content } & 0.205 & 0.550 & 0.664 & 0.599 & 0.146 \\
\hline \multicolumn{2}{|c|}{ Drying temperature } & $<0.001$ & 0.042 & 0.012 & 0.036 & 0.011 \\
\hline \multicolumn{2}{|c|}{ Interaction } & 0.010 & 0.125 & 0.348 & 0.285 & 0.254 \\
\hline
\end{tabular}

Means with different letters within each column are significantly different $(P<0.05)$.

${ }^{1}$ Values are least square means of six replicate cages of two broiler chickens per cage.

${ }^{2}$ Organic matter

${ }^{3}$ Non-starch organic matter. 
Table 4. Effect of drying temperature and moisture content at harvest on faecal starch digestibility coefficient, apparent faecal digestibility coefficient of protein, organic matter and non-starch organic matter retention and the apparent metabolisable energy corrected for a zero-nitrogen balance of Var II $(n=6)^{1}$

\begin{tabular}{|c|c|c|c|c|c|c|}
\hline \multirow[b]{2}{*}{$\begin{array}{l}\text { Moisture } \\
\text { content }\end{array}$} & \multirow[b]{2}{*}{$\begin{array}{c}\text { Drying } \\
\text { temperature }\end{array}$} & \multirow[b]{2}{*}{$\begin{array}{l}\text { Faecal digestibility coefficient } \\
\text { Starch }\end{array}$} & \multirow[b]{2}{*}{$\begin{array}{c}\text { Apparent faecal digestibility coefficient of } \\
\text { Protein }\end{array}$} & \multicolumn{2}{|c|}{ Retention } & \multirow[b]{2}{*}{$\begin{array}{l}\text { AMEn }(\mathrm{MJ} / \mathrm{kg} \\
\mathrm{DM})\end{array}$} \\
\hline & & & & $\begin{array}{l}\mathrm{OM}^{3} \\
(\%)\end{array}$ & $\begin{array}{l}\mathrm{NSOM}^{4} \\
(\%)\end{array}$ & \\
\hline \multirow[t]{3}{*}{$34 \%$} & $54^{\circ} \mathrm{C}$ & $0.985^{\mathrm{ab}}$ & 0.651 & 84.2 & 43.6 & 16.2 \\
\hline & $90^{\circ} \mathrm{C}$ & $0.986^{\mathrm{ab}}$ & 0.640 & 83.7 & 42.7 & 16.4 \\
\hline & $125^{\circ} \mathrm{C}$ & $0.987^{\mathrm{ab}}$ & 0.637 & 84.1 & 45.5 & 16.0 \\
\hline \multirow[t]{3}{*}{$24.5 \%$} & $54^{\circ} \mathrm{C}$ & $0.992^{\mathrm{a}}$ & 0.659 & 84.7 & 40.7 & 15.9 \\
\hline & $90^{\circ} \mathrm{C}$ & $0.982^{\mathrm{bc}}$ & 0.678 & 84.3 & 42.8 & 15.9 \\
\hline & $125^{\circ} \mathrm{C}$ & $0.978^{c}$ & 0.673 & 83.1 & 42.3 & 15.7 \\
\hline SEM & & 0.0022 & 0.0218 & 0.64 & 2.14 & 0.11 \\
\hline \multicolumn{7}{|c|}{ Main effects } \\
\hline \multicolumn{7}{|c|}{ Moisture content } \\
\hline $34 \%$ & & 0.986 & 0.643 & 84.0 & 44.0 & 16.2 \\
\hline $24.5 \%$ & & 0.984 & 0.670 & 84.1 & 41.9 & 15.8 \\
\hline \multicolumn{7}{|c|}{ Drying temperature } \\
\hline $54^{\circ} \mathrm{C}$ & & 0.989 & 0.655 & 84.5 & 42.2 & $16.1^{\mathrm{ab}}$ \\
\hline $90^{\circ} \mathrm{C}$ & & 0.984 & 0.659 & 84.0 & 42.8 & $16.1^{\mathrm{a}}$ \\
\hline $125^{\circ} \mathrm{C}$ & & 0.983 & 0.655 & 83.6 & 43.9 & $15.8^{\mathrm{b}}$ \\
\hline \multicolumn{7}{|l|}{ P-value } \\
\hline Moistu & & 0.287 & 0.145 & 0.935 & 0.266 & 0.001 \\
\hline Drying & ture & 0.047 & 0.976 & 0.409 & 0.732 & 0.045 \\
\hline Intera & & 0.009 & 0.750 & 0.388 & 0.709 & 0.777 \\
\hline
\end{tabular}

Means with different letters within each column are significantly different $(P<0.05)$.

${ }^{1}$ Values are least square means of six replicate cages of two broiler chickens per cage.

${ }^{2}$ Least square means of maize dried at $125^{\circ} \mathrm{C}$ and harvest at $24.5 \%$ and $34 \%$ are values measured based on 5 replicate cages ( $n=5$ ) because of the two outliers that were removed.

${ }^{3}$ Organic matter

${ }^{4}$ Non-starch organic matter.

Table 5. Pearson's correlation between in vivo digestibilities observed of Var I.

\begin{tabular}{|c|c|c|c|c|}
\hline Var I & AMEn & $\begin{array}{l}\text { Faecal digestibility coefficient of } \\
\text { starch }\end{array}$ & $\begin{array}{l}\text { Apparent faecal digestibility coefficient of } \\
\text { protein }\end{array}$ & $\begin{array}{l}\text { Retention of } \\
\mathrm{OM}^{1}\end{array}$ \\
\hline Faecal digestibility coefficient of starch & $0.557^{* *}$ & & & \\
\hline $\begin{array}{l}\text { Apparent faecal digestibility coefficient of } \\
\text { protein }\end{array}$ & $0.817^{* * *}$ & 0.255 & & \\
\hline Retention of $\mathrm{OM}$ & $0.973^{* * *}$ & $0.556^{* *}$ & $0.855^{* * *}$ & \\
\hline Retention of $\mathrm{NSOM}^{2}$ & $0.917^{* * *}$ & 0.320 & $0.909 * * *$ & $0.956^{* * *}$ \\
\hline
\end{tabular}

${ }^{*}$, significant $(0.01<\mathrm{P}<0.05) ;{ }^{* *}$, highly significant $(0.001<\mathrm{P}<0.01){ }^{* * *}$, very highly significant $(\mathrm{P}<0.001)$.

${ }^{1}$ Organic matter.

${ }^{2}$ Non-starch organic matter.

Table 6. Pearson's correlation between in vivo digestibilities observed of Var II.

\begin{tabular}{|c|c|c|c|c|}
\hline Var II & AMEn & $\begin{array}{l}\text { Faecal digestibility coefficient of } \\
\text { starch }\end{array}$ & $\begin{array}{l}\text { Apparent faecal digestibility coefficient of } \\
\text { protein }\end{array}$ & $\begin{array}{l}\text { Retention of } \\
\mathrm{OM}^{1}\end{array}$ \\
\hline Faecal digestibility coefficient of starch & $0.419^{*}$ & & & \\
\hline $\begin{array}{l}\text { Apparent faecal digestibility coefficient of } \\
\text { protein }\end{array}$ & $0.346^{*}$ & -0.126 & & \\
\hline Retention of OM & $0.783^{* * *}$ & $0.367^{*}$ & $0.628^{* * *}$ & \\
\hline Retention of NSOM ${ }^{2}$ & $0.714^{* * *}$ & -0.103 & $0.689^{* * *}$ & $0.864^{* * *}$ \\
\hline
\end{tabular}

${ }^{*}$, significant $(0.01<\mathrm{P}<0.05)$; $^{* *}$, highly significant $(0.001<\mathrm{P}<0.01)$; *** $^{* *}$ very highly significant $(\mathrm{P}<0.001)$.

'Organic matter.

${ }^{2}$ Non-starch organic matter.

a country or region, due to a favoured type of endosperm. However, the hand dissection method used in this study may have led to approximations, because the separation of the floury and corneous endosperm was subjectively conducted by the experimenter. The standard deviation of vitreousness reached 5\% (data not shown).

To assess the effect of the drying process on maize, this study used grains dried at different temperatures using varying times to reach $15 \%$ moisture content. Even if the duration of drying may affect the economical aspect of this process, it was assumed that the duration of drying did not significantly affect the AME in broiler chickens, since this factor did not significantly modify the digestibility or the structural characteristics of maize grain components (e.g. proteins and starch).

Indeed, during drying, the effect of temperature was significant only at the beginning of the process, when grain still contained enough moisture. Malumba et al. (2010) demonstrated that the differences observed were mainly due to the effect of temperature and humidity in the early stages of the process. When the moisture content of corn was kept constant (HMT) below 15\%, no perceptible change was observed on starch granules structure, even for higher heat treatment. Odjo et al. (2012) reported that a long time was needed to decrease 

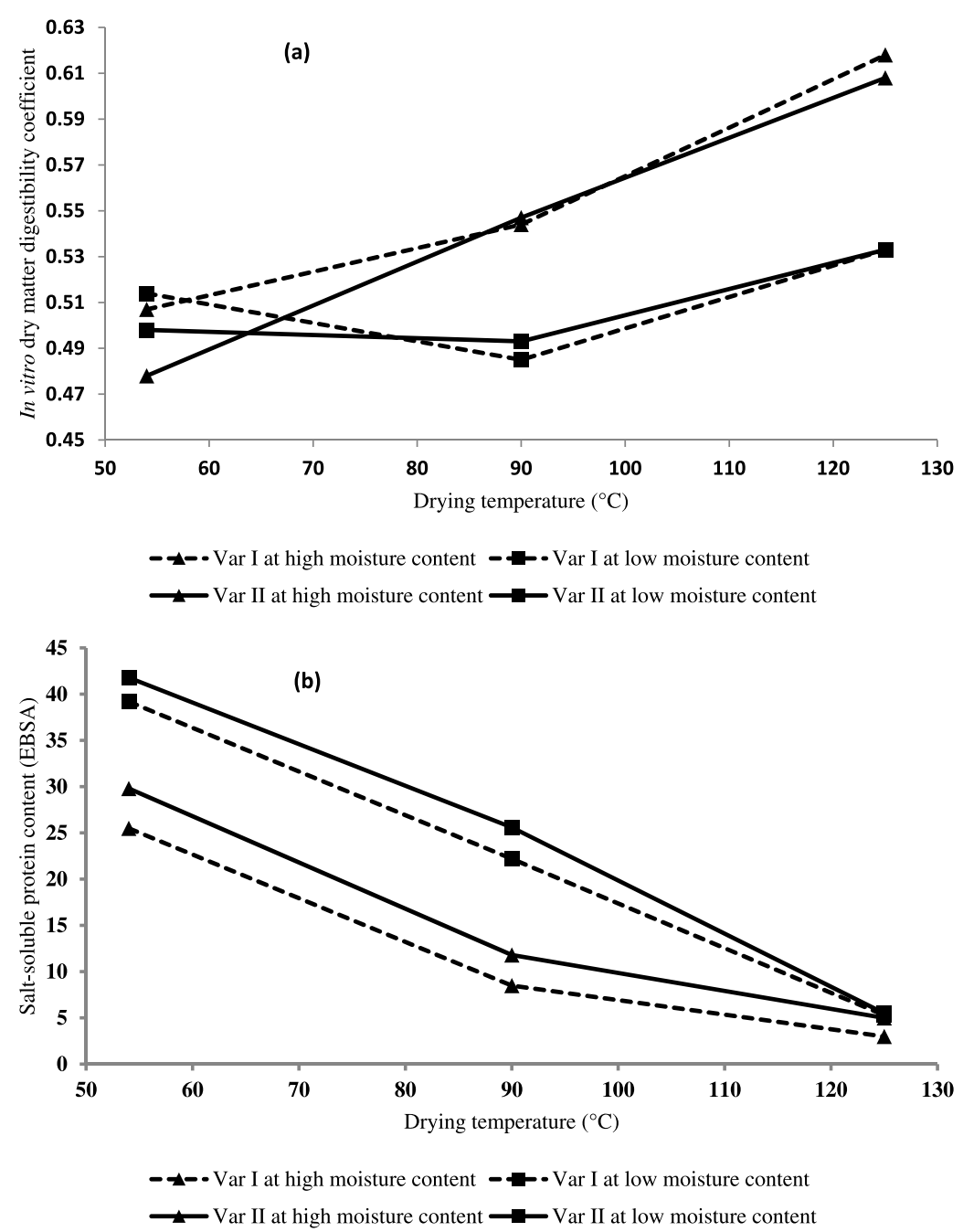

Figure 1. Impact of the drying temperature on in vitro dry matter digestibility (IVDMD) (a) and salt-soluble protein (SSP) content (b) of maize grain. $\mathrm{EBSA}=$ equivalent bovine serum albumin.

the moisture content of corn grain when low-temperature drying was applied, which did not significantly affect the corn grain in vitro digestibility or protein solubility.

Tube-feeding broilers were employed in this study in order to assess the effect of the drying process on maize digestion. Moreover, Huart et al. (2018) showed that particle size distribution after milling was affected by the drying process applied to maize grain, which can affect broiler behaviour and, consequently, the composition of ingested feed in mash diet. For scientific investigation purposes, tube-feeding would allow evaluation of the effects of drying on maize nutrient value, without the influence of feed selectivity (Huart et al. 2018). Similar tube-feeding techniques were recently used in other studies to assess the nutritional value of feedstuffs (Aardsma et al. 2017; Corray et al. 2018; Munoz et al. 2018).

According to Cowieson (2005), the metabolisable energy of the maize can vary by more than $2.09 \mathrm{MJ} / \mathrm{kg}$ which could affect growth performance in broilers. The assumption made in the current study was that drying temperature and MC could account for a huge part of this variation. The results showed that maize AMEn was significantly decreased at $125^{\circ} \mathrm{C}(0.29-$ $0.41 \mathrm{MJ} / \mathrm{kg} \mathrm{DM}$ ) without any significant interaction of drying temperature and initial MC. Kaczmarek et al. (2013) observed that the AMEn of a maize-based diet was reduced by $0.41 \mathrm{MJ} /$ $\mathrm{kg}$ when temperatures increased from $60^{\circ} \mathrm{C}$ to $140^{\circ} \mathrm{C}$. Métayer et al. (2009) showed that increasing drying temperature from $80^{\circ} \mathrm{C}$ to $140^{\circ} \mathrm{C}$ decreased the AMEn by $0.33 \mathrm{MJ} / \mathrm{kg} \mathrm{DM}$.
The chemical composition of dried maize grain (Table 2) and freeze-dried maize (Table 1) were the same, suggesting that the drying process did not affect its composition. This was in agreement with results of Barrier-Guillot et al. (1993) and Métayer et al. (2009). The variation observed in maize nutritional value only resulted from the effect of the drying process on the digestibility of maize components. The AMEn of maize grain is influenced by the physiological processes that occur in the whole digestive tract according to the activity of digestive enzymes and the microbiota. Thus, in order to understand the variation in maize metabolisable energy, this study focussed on the total tract instead of ileal digestibility of maize components.

As expected, the correlation between AMEn and $\mathrm{OM}_{\mathrm{R}}$ was very high $\left(\mathrm{R}^{=} 0.973\right.$ for Var I and 0.783 for Var II). Since the organic matter of maize is mainly composed of starch, it was supposed that variation in AMEn was mostly explained by starch digestibility. However, the correlation between faecal starch digestibility and AMEn was low $(\mathrm{R}=0.557$ and 0.419 for Var I and II, respectively). A significant interaction between factors was observed, which suggested that the decrease in starch digestibility coefficient with increasing drying temperature may be modulated differently according to the $\mathrm{MC}$ at harvest. However, starch digestibility was high (98\%) with low variation due to drying temperature and moisture content, which was in agreement with the study of Barrier-Guillot et al. (1993) on tubefed broilers, and with studies by Huart et al. (2018) based on ad 
libitum consumption. It is likely that most digestion occurred in the small intestine because the ileal and total digestibilities of starch from a maize-based diet were found to be very similar in a previous experiment (Huart et al. 2018). The low effect of factors on the starch digestibility was probably due to the high capacity of broilers to digest this material. In the current experiment, the maize was very finely ground, which probably facilitated its digestion. However, Jacobs et al. (2010) demonstrated that the particle size of maize had no consistent effects on metabolisable energy and amino-acid digestibility in broilers at $21 \mathrm{~d}$ of age. It is known that, with coarser particles, the grinding activity of the gizzard reduces the size of the feed particles and most of them, on entering the duodenum, are smaller than $100 \mu \mathrm{m}$ (Svihus et al. 1997; Hetland et al. 2002), facilitating better contact with alpha-amylase. In the current study, maize grains were ground to pass through a $500 \mu \mathrm{m}$ sieve, which was much larger than the potential gizzard reduction of particle recorded in previous studies. Moreover, amylase activity in the jejunum content of broiler chickens is three times higher than in pigs (Svihus 2014). These conditions allow a rapid and efficient digestion of maize starch in the intestine, even if transit time of particles rich in starch is very short (Svihus 2014). So, despite the significant effect of drying temperature, it can be concluded that differences in the faecal starch digestibility coefficient observed in this study were of little significance for broiler chickens.

The origin of AMEn losses at high drying temperatures seemed to be linked to other maize constituents (non-starch organic matter), as seen in the high correlation between them (Tables 5 and 6). This was confirmed by the high correlation between $\mathrm{NSOM}_{\mathrm{r}}$ and $\mathrm{OM}_{\mathrm{R}}$ (Tables 5 and 6). It was supposed that protein, which is the second most important nutrient fraction in maize, significantly contributed to the decrease in AMEn. Indeed, it is well known that high drying temperature affects protein digestibility (Wall et al. 1975; Odjo et al. 2012; Peplinski et al. 1994; Malumba et al. 2015). A high correlation between $\mathrm{NSOM}_{\mathrm{R}}$ and ADP (Tables 5 and 6) provided evidence to support this. It was found that increasing drying temperature significantly decreased the ADP and $\mathrm{NSOM}_{\mathrm{R}}$ of Var I, which was consistent with previous studies. Carvalho et al. (2009) found a decrease in true digestibility of lysine, methionine, threonine and tryptophan when increasing drying temperature from $80^{\circ} \mathrm{C}$ to $120^{\circ} \mathrm{C}$. Kaczmarek et al. (2013) observed that the ileal protein digestibility of soft corn, with an initial MC of $36 \%$, decreased by 4.8 points when increasing drying temperature from $60^{\circ} \mathrm{C}$ to $140^{\circ} \mathrm{C}$. This reduction was associated with protein insolubilisation and disulphide bond formation. The absence of any significant effect of drying temperature on ADP of Var II suggested that this was less susceptible to heat damage than the protein of Var I. The extent of AMEn reduction with increasing drying temperature was lower and led less correlation between ADP and AMEn compared to Var I. Kaczmarek et al. (2013) concluded that the harder the endosperm, the less susceptible grain was to heat damage. The variation in protein digestibility observed in the present study may be a consequence of a more favourable kernel structure or a faster decrease in MC that limited protein denaturation, as postulated by Odjo et al. (2018).

The AMEn of the maize was less for low harvest MC (Tables 3 and 4; $0.38 \mathrm{MJ} / \mathrm{kg}$ for Var II and $0.17 \mathrm{MJ} / \mathrm{kg}$ for Var I). These results showed that modifications inside grains after maize maturity are likely to affect their AMEn. The increase in zein and glutelin during grain development
(Bressani and Conde 1961) may result in poor postmaturation maize protein quality since zein is low in lysine, the first limiting amino acid for animal growth. Moreover, glutelin which is a main constituent of the protein matrix (Christianson et al. 1969) surrounding starch granules, increases with maturity (Xu et al. 2010). The association between these components may have consequences on enzyme accessibility to starch granules. It is possible that the slight decrease in lipid content and the increase in NDF content observed in the current study (Table 1) yielded less metabolisable energy for broilers. According to current knowledge, there are no publications that have aimed at assessing the variation in maize components and their interactions after maize maturity, despite possible reorganisation reported in the literature (Ajayi et al. 2005; Huart et al. 2018). Further studies are needed to give more information in order to understand the loss of AMEn during the desiccation stage observed, and the implication with regard to maize nutrient digestibility and the growth of broiler chickens. Despite the absence of any significant effect of initial MC, the more pronounced decrease in ADP at high MC for Var I indicated that this may be due to heat-induced protein denaturation, as demonstrated by Rivera et al. (1978) and Gausman et al. (1952).

The lower ADP of Var II (5-6 points) compared with Var I possibly resulted from lower protein content in Var II (Table 1), making endogenous losses proportionally more significant compared to protein from excreta. It was possible that variations in kernel composition (e.g. protein, amylose) or structure affected the level of endogenous losses. However, these differences may have arisen from variation in protein digestibility, according to the maize vitreousness. Such adverse effects have been observed in ruminants (Corona et al. 2006) while its effect remains unclear in poultry. Kaczmarek et al. (2013) observed that the ileal protein digestibility in diets formulated with soft maize was higher than that formulated with hard maize. These differences are likely to affect broilers growth performance especially in the grower phase, when maize is the main ingredient of the diet (Kaczmarek et al. 2013).

It has been demonstrated that in order to maintain corn with high nutritional value, drying at low temperature $\left(<90^{\circ}\right.$ C) is needed. However, such drying conditions greatly increase the processing time and, consequently, cost. The time required for processing was more than two times higher at $90^{\circ} \mathrm{C}$ and more than six times higher at $54^{\circ} \mathrm{C}$ compared with a drying at $125^{\circ} \mathrm{C}$. It may be postulated that a similar trend could be observed in a drying tower usually used for corn drying. Further studies need to be carried out to determine the optimal time of processing to maintain high corn nutritional value and avoid excessive costs.

Since there is not a systematic assessment of nutritional potential of corn batches because of the lack of good predictors of maize nutritional value for broilers nutrition, feed formulations are based on standard AMEn values, which may result in over or underestimation of dietary energy, which may subsequently affect broiler growth performance. In this context, Tervilä-Wilo et al. (1996) developed an in vitro protocol to mimic digestive process in broilers. More recently, a determination of SSP solubility was proposed to assess the nutritional value of dried maize for poultry by several authors (Métayer et al. 2009; Gehring et al. 2013). These variables were measured on dried maize 
grain to assess their predictive potential of maize metabolisable energy.

The IVDMD of maize grain increased with drying temperature, especially for grains harvested at high MC (Figure 1a). Odjo et al. (2018) showed that the increase in DM digestibility was due to the increase in starch digestibility at high drying temperatures, even if protein digestibility was depressed under the same conditions. This led to a poor relationship with AMEn $\left(\mathrm{R}^{2}=0.088\right)$. The in vitro protocol used in the current study was a poor estimator of the in vivo digestibility of dried maize for broilers. Factors that may affect the response of in vitro digestion protocols and its correlation with animal response include digestion time, temperature, $\mathrm{pH}$, enzyme activity, the nature of the digestive enzymes used or environmental hydrodynamics, as demonstrated by Huart et al. (2020), as well as the form of presentation of ingredients, including their particle size, structure and complexity.

The second predictive variable measured in dried maize grain was SSP (Figure 1b). A linear decrease in SSP content with increasing drying temperature from $54^{\circ} \mathrm{C}$ to $125^{\circ} \mathrm{C}$ was observed, while the decrease in AMEn was initiated beyond $90^{\circ} \mathrm{C}$ for both varieties. This was consistent with the decrease in SSP content reported by Wall et al. (1975) within the same range of temperatures. High temperature causes aggregation and insolubilisation of albumin (Peplinski et al. 1994). Wall et al. (1975) showed that the formation of new intermolecular disulphides bonds causes insolubilisation of SSP. Moreover, high initial MC improved AMEn while, under these conditions, SSP content was lower, as observed by Odjo et al. (2012) and Malumba et al. (2008). This resulted in a poor relationship between the AMEn of the maize and its SSP content $\left(\mathrm{R}^{2}=0.090\right)$.

While in vivo experimentation showed that protein degradation during the drying process probably reduced maize nutritive value, SSP content failed to predict the AMEn value. It is believed that SSP content is not representative of the nutritional losses of maize grain during drying because SSP represents only a small fraction of total maize protein with a particular amino-acid profile. Indeed, SSP is composed of albumin and globulin and represent only $17 \%$ of the total protein (Malumba et al. 2008) and are mainly localised in the maize germ (Wall and Paulis 1978). The main proteins of the maize are zein and glutelin found in the endosperm (Wall and Paulis 1978). The high concentration of lysine in SSP differs from the other maize proteins. Rivera et al. (1978) showed that lysine was more susceptible than all other amino acids to heat degradation. Among protein, albumin was the most readily heat-denatured protein according to Malumba et al. (2008). The different amino-acid profile and location of SSP make them more susceptible to drying temperature compared with whole maize protein.

\section{Conclusions}

In conclusion, this study showed that the MC at harvest and the drying temperature affected the AMEn of the maize grain. For both varieties, harvesting maize just after the appearance of the black layer, at high $\mathrm{MC}$, and limiting drying temperature to a maximum of $90^{\circ} \mathrm{C}$ could improve AMEn of maize grain by $0.65 \mathrm{MJ} / \mathrm{kg} \mathrm{DM}$, which could have some beneficial effect for broiler performance. The decrease in AMEn at high drying temperatures was mainly attributed to the degradation of NSOM, while faecal starch digestibility only varied slightly and remained very high (0.97-0.98). Unfortunately, this treatment will increase time and processing costs and the economic sustainability of this model needs to be evaluated in further studies. Finally, the in vitro dry matter digestibility and SSP content did not allow the prediction of energy content from dried maize for broilers. Further research is needed to confirm these results using samples varying widely in origin and to determine protocols that can adequately predict maize nutritional value. Such a protocol will ensure optimal feed formulation and prevent poor broiler performance, as the nutritional quality of maize can vary from batch to batch.

\section{Acknowledgments}

The authors are grateful to Nathalie Peclers, Sylvie Mabille, Lynn Doran and Romain Thomas of the University of Liège, Gembloux Agro BioTech for their technical support. The authors wish to express their thanks to Hélène Soyeurt (Laboratoire de Statistique, Informatique et Modélisations appliquées à la bioingénierie, Gembloux Agro Bio-Tech) for her advice on statistical analyses.

\section{Disclosure statement}

No potential conflict of interest was reported by the authors.

\section{Funding}

This research was funded by the Direction Génerale Opérationnelle de l'Agriculture, des Ressources Naturelles et de l'Environnement of Walloon government through the project MAISECVOL.

\section{References}

Aardsma, M. P., R. D. Mitchell, and C. M. Parsons. 2017. "Relative Metabolizable Energy Values for Fats and Oils in Young Broilers and Adult Roosters.” Poultry Science 96 (7): 2320-2329. doi:10.3382/ps/ pex028.

AFNOR. 2008. Méthode Promatest D'évaluation De La Dénaturation Des Protéines Thermosensibles NF-V03-741. Paris, France: Association Française de Normalisation.

Ajayi, S. A., G. Rưhl, and J. M. Greef. 2005. "Physiological Basis of Quality Development in Relation to Compositional Changes in Maize Seed." Seed Science and Technology 33 (3): 605-621. doi:10.15258/sst.2005.33.3.08.

AOAC. 1990. Official Methods of Analysis. 15th. Arlington, VA: Association of Official Analytical Chemists.

Barrier-Guillot, B., Z. C. Jondreville, A. M. Chagneau, M. Larbier, and M. Leuillet. 1993. "Effect of Heat Drying Temperature on the Nutritive Value of Corn in Chickens and Pigs." Animal Feed Science and Technology 41 (2): 149-159. doi:10.1016/0377-8401(93) 90120-9.

Bhuiyan, M. M., A. F. Islam, and P. A. IJI. 2011. "Response of Broiler Chickens to Diets Containing Artificially Dried High-Moisture Maize Supplemented with Microbial Enzymes." South African Journal of Animal Science 40 (4): 348-362. doi:10.4314/sajas. v40i4.65257.

Bressani, R., and R. Conde. 1961. "Changes in the Chemical Composition and in the Distribution of Nitrogen of Maize at Different Stages of Development." Cereal Chemistry 38: 76-84.

Brown, W. L., M. S. Zuber, L. L. Darrah, and D. V. Glover. 1985. "Origin, Adaptation, and Types of Corn." In National Corn Handbook, 1-6. Ames: Iowa State University.

Carvalho, D. C. O., L. F. T. Albino, H. S. Rostagno, J. E. Oliveira, J. G. Vargas Júnior, R. G. Toledo, C. H. R. Costa, S. R. F. Pinheiro, and R. M. SouzA. 2004. "Chemical and Energy Composition of Corn Sample under Different Drying Temperature and Storage Periods." Revista Brasileira De Zootecnia 33 (2): 358-364. doi:10.1590/S151635982004000200012 . 
Carvalho, D. C. O., L. F. T. Albino, J. G. Vargas Junior, R. S. Toledo, J. E. Oliveira, and R. M. Souza. 2009. "Coeficiente De Digestibilidade Verdadeira Dos Aminoácidos E Valores De Aminoácidos Digestíveis Do Milho Submetido a Diferentes Temperaturas De Secagem E Períodos De Armazenamento." Revista Brasileira De Zootecnia 38 (5): 850-856. doi:10.1590/S1516-35982009000500010.

Christianson, D. D., H. C. Nielsen, U. Khoo, M. J. Wolf, and J. S. Wall. 1969. "Isolation and Chemical Composition of Bodies and Matrix Proteins in Corn Endosperm." Cereal Chemistry 46 (April): 372-381.

Corona, L., F. N. Owens, and R. A. Zinn. 2006. "Impact of Corn Vitreousness and Processing on Site and Extent of Digestion by Feedlot Cattle." Journal of Animal Science 84 (11): 3020-3031. doi:10.2527/jas.2005-603.

Corray, S. P., P. L. Utterback, and C. M. Parsons. 2018. "Nutritional Evaluation of Glutenol: A Co-Product of Ethanol Production." Poultry Science 97 (11): 3987-3991. doi:10.3382/ps/pey246.

Cowieson, A. J. 2005. "Factors that Affect the Nutritional Value of Maize for Broilers." Animal Feed Science and Technology 119 (3-4): 293-305. doi:10.1016/j.anifeedsci.2004.12.017.

DALE, N. 1994. "Relationship between Bushel Weight, Metabolizable Energy, and Protein Content of Corn from an Adverse Growing Season." Journal of Applied Poultry Research 3: 83-86. doi:10.1093/ japr/3.1.83.

Dombrink-Kurtzman, M. A., and J. A. Bietz. 1993. "Zein Composition in Hard and Soft Endosperm of Maize." Cereal Chemistry 70 (1): 105-108. http://www.aaccnet.org/cerealchemistry/abstracts/1993/ CC1993a22.asp.

Gausman, H. W., J. H. Ramser, G. H. Dungan, F. R. Earle, M. M. Macmasters, H. H. Hall, and P. D. Baird. 1952. "Some Effects of Artificial Drying of Corn Grain." Plant Physiology 27 (4): 794-802. doi:10.1104/pp.27.4.794.

Gehring, C. K., M. R. Bedford, A. J. Cowieson, and W. A. Dozier III. 2012. "Effects of Corn Source on the Relationship between in Vitro Assays and Ileal Nutrient Digestibility." Poultry Science 91 (8): 1908-1914. doi:10.3382/ps.2012-02175.

Gehring, C. K., A. J. Cowieson, M. R. Bedford, and W. A. Dozier III. 2013. "Identifying Variation in the Nutritional Value of Corn Based on Chemical Kernel Characteristics." World's Poultry Science Journal 69 (2): 299-312. doi:10.1017/S0043933913000317.

Giuberti, G., A. Gallo, M. Moschini, C. Cerioli, and F. Masoero. 2013. "Evaluation of the Impact of Maize Endosperm Vitreousness on in Vitro Starch Digestion, Dry Matter Digestibility and Fermentation Characteristics for Pigs." Animal Feed Science and Technology 186 (1-2): 71-80. doi:10.1016/j.anifeedsci.2013.08.011.

Hetland, H., B. Svihus, and V. Olaisen. 2002. "Effect of Feeding Whole Cereals on Performance, Starch Digestibility and Duodenal Particle Size Distribution in Broiler Chickens." British Poultry Science 43 (3): 416-423. doi:10.1080/00071660120103693.

Huart, F., P. Malumba, S. Odjo, W. Al-Izzi, F. Béra, and Y. Beckers. 2018. "In Vitro and in Vivo Assessment of the Effect of Initial Moisture Content and Drying Temperature on the Feeding Value of Maize Grain." British Poultry Science 59 (4): 452-462. doi:10.1080/ 00071668.2018.1477253.

Huart, F., N. Peclers, F. Béra, Y. Beckers, and P. Malumba. 2020. "The Effect of Hydrodynamic Conditions on the Monogastric-like in Vitro Digestion of Maize Flours Dried at Different Temperatures." LWT-Food Science and Technology 120 (February): 108917. doi:10.1016/j.lwt.2019.108917.

Jacobs, C. M., P. L. Utterback, and C. M. Parsons. 2010. "Effects of Corn Particle Size on Growth Performance and Nutrient Utilization in Young Chicks." Poultry Science 89 (3): 539-544. doi:10.3382/ ps.2009-00434.

Janas, S., S. Boutry, P. Malumba, L. Vander Elst, and F. Béra. 2010. "Modelling Dehydration and Quality Degradation of Maize during Fluidized-Bed Drying." Journal of Food Engineering 100 (3): 527-534. doi:10.1016/j.jfoodeng.2010.05.001.

Kaczmarek, S. A., A. J. Cowieson, D. Józefiak, and M. Bochenek. 2007. "The Effect of Drying Temperature and Exogenous Enzymes Supplementation on the Nutritional Value of Maize for Broiler Chickens." World Poultry Science Association, Proceedings of the 16th European Symposium on Poultry Nutrition, Starsbourg, 555-558.

Kaczmarek, S. A., A. J. Cowieson, D. Jozefiak, and A. Rutkowski. 2013. "Effect of Maize Endosperm Hardness, Drying Temperature and Microbial Enzyme Supplementation on the Performance of Broiler
Chickens." Animal Production Science 54 (7): 956-965. doi:10.1071/ AN13113.

Larbier, M., and B. LeClercQ. 1992. Nutrition et Alimentation Des Volailles. Paris (France): INRA. http://prodinra.inra.fr/record/114212.

LeEson, S., A. Yersin, and L. VolKer. 1993. "Nutritive Value of the 1992 Corn Crop." Journal of Applied Poultry Research 2: 208-213. doi:10.1093/japr/2.3.208.

Lessire, M. 1990. "Effect Of Feeding Technique, Ad Libitum, dry or wet force feeding, on the metabolisable energy values of raw materials for poultry." British Poultry Science 31 (4): 785-793. doi:10.1080/ 00071669008417309.

Li, Y., R. Duan, F. Shi, L. Wang, and Z. Chen. 2017. "Effects of High-Temperature Air Fluidization (HTAF) on the Structural, Functional, and in Vitro Digestive Properties of Corn." Starch Stärke 69 (5-6): 1600137. doi:10.1002/star.201600137.

Malumba, P., C. Boudry, O. Roiseux, J. Bindelle, Y. Beckers, and F. BÉrA. 2015. "Chemical Characterisation and in Vitro Assessment of the Nutritive Value of Co-Products Yield from the Corn Wet-Milling Process." Food Chemistry 166: 143-149. doi:10.1016/j.foodchem.2014.06.001.

Malumba, P., S. Janas, O. Roiseux, G. Scrinalve, T. Masainango, M. Sindic, C. Deroanne, and F. Bera. 2010. "Comparative Study of the Effect of Drying Temperatures and Heat-moisture Treatment on the Physiochemical and Functional Properties of Corn Starch." Carbohydrate Polymers 79 (3): 633-641. doi:10,1016/j. carpl.2009.09.013.

Malumba, P., S. Odjo, C. Boudry, S. Danthine, J. Bindelle, Y. Beckers, and F. BÉrA. 2014. "Physicochemical Characterization and in Vitro Assessment of the Nutritive Value of Starch Yield from Corn Dried at Different Temperatures." Starch - Stärke 66 (7-8): 738-748. doi:10.1002/star.201400012.

Malumba, P., C. Vanderghem, C. Deroanne, and F. Béra. 2008. "Influence of Drying Temperature on the Solubility, the Purity of Isolates and the Electrophoretic Patterns of Corn Proteins." Food Chemistry 111 (3): 564-572. doi:10.1016/j.foodchem.2008.04.030.

Marquardt, R. R. 1983. "A Simple Spectrophotometric Method for the Direct Determination of Uric Acid in Avian Excreta." Poultry Science 62 (10): 2106-2108. doi:10.3382/ps.0622106.

Marton, L. C., T. Arendas, P. Bonis, E. Nagy, D. Q. Lap, and Z. Berzsenyi. 2007. "Drying down after Physiological Maturity." Maydica 52 (3): 319-324.

Métayer, J.-P., A.-M. Debicki-Garnier, and F. Skiba. 2009. "Le Promatest : Un Bon Indicateur de La Qualité Du Séchage et de La Valeur Alimentaire Du Maïs Grain Chez Les Volailles." World Poultry Science Association, Proceeding of the 8th Avian French Research Day, St Malo, 264-268.

Munoz, J. A., C. D. Hanna, P. L. Utterback, and C. M. Parsons. 2018. "Phosphorus Retention in Corn, Spray Dried Plasma Protein, Soybean Meal, Meat and Bone Meal, and Canola Meal Using a Precision-Fed Rooster Assay." Poultry Science 97 (12): 4324-4329. doi:10.3382/ps/pey322.

Odjo, S., F. Béra, Y. Beckers, G. Foucart, and P. Malumba. 2018 "Influence of Variety, Harvesting Date and Drying Temperature on the Composition and the in vitro Digestibility of Corn Grain." Journal of Cereal Science 79: 218-225. doi:10.1016/j.jcs.2017.10.008.

Odjo, S., F. Béra, N. Jacquet, A. Richel, and P. Malumba. 2016. "Characterization of Saccharides Released during an in Vitro Pepsin-Pancreatin Digestion of Corn Flour Using HPAEC-PAD." Starch - Stärke 68 (7-8): 691-699. doi:10.1002/star.201500281.

Odjo, S., P. Malumba, Y. BeCKers, and F. Béra. 2015. "Impact of Drying and Heat Treatment on the Feeding Value of Corn. A Review." Biotechnology, Agronomy, Society and Environment 19 (3): 301-312.

Odjo, S., P. Malumba, J. Dossou, S. Janas, and F. Béra. 2012. "Influence of Drying and Hydrothermal Treatment of Corn on the Denaturation of Salt-Soluble Proteins and Color Parameters." Journal of Food Engineering 109 (3): 561-570. doi:10.1016/j. jfoodeng.2011.10.023.

Peplinski, A. J., J. W. Paulis, J. A. Bietz, and R. Pratt. 1994. "Drying of High-Moisture Com: Changes in Properties and Physical Quality." Cereal Chemistry 71 (2): 129-I33. http://www.aaccnet.org/cereal chemistry/backissues/1994/71_129.pdf.

Rivera, P. H., E. R. Peo, D. Flowerday, T. D. Crenshaw, B. D. Moser, and P. J. Cunningham. 1978. "Effect of Maturity and Drying Temperature on Nutritional Quality and Amino Acid Availability 
of Normal and Opaque-2 Corn for Rats and Swine." Journal of Animal Science 46 (5): 1275-1286. doi:10.2527/jas1978.4641024x.

Rotter, B. A., A. A. Frohlich, R. G. Rotter, and R. R. Marquardt. 1989. "Research Note: Estimation of Apparent Protein Digestibility Using Uric Acid-Corrected Nitrogen Values in Poultry Excreta." Poultry Science 68 (2): 327-329. doi:10.3382/ps.0680327.

SiBbalD, I. R. 1978. "The Effect of the Duration of the Time Interval between Assays on True Metabolizable Energy Values Measured with Adult Roosters." Poultry Science 57 (2): 455-460. doi:10.3382/ps.0570455.

Svinus, B. 2014. "Starch Digestion Capacity of Poultry." Poultry Science 93 (9): 2394-2399. doi:10.3382/ps.2014-03905.

Svinus, B., O. Herstad, C. W. Newman, and R. K. Newman. 1997. "Comparison of Performance and Intestinal Characteristics of Broiler Chickens Fed on Diets Containing Whole, Rolled or Ground Barley." British Poultry Science 38 (5): 524-529. doi:10.1080/00071669708418032.

Teeter, R. G., M. O. Smith, E. Murray, and H. Hall. 1984. "Force Feeding Methodology and Equipment for Poultry." Poultry Science 63 (3): 573-575. doi:10.3382/ps.0630573.

Tervilä-Wilo, A., T. Parkkonen, A. Morgan, K. Poutanen, P. Heikkinen, and K. Autio. 1996. "In Vitro Digestion of
Wheat Microstructure with Xylanase and Cellulase from Trichoderma Reesei." Journal of Cereal Science 24 (3): 215-225. doi:10.1006/jcrs.

Van Soest, P. J., J. B. Robertson, and B. A. Lewis. 1991. "Methods for Dietary Fiber, Neutral Detergent Fiber, and Nonstarch Polysaccharides in Relation to Animal Nutrition." Journal of Dairy Science 74 (10): 3583-3597. doi:10.3168/jds.S00220302(91)78551-2.

Wall, J. S., C. James, and G. L. Donaldson. 1975. "Corn Proteins: Chemical and Physical Changes during Drying of Grain." Cereal Chemistry 52 (6): 779-790. http://www.fstadirect.com/GetRecord. aspx?AN=1976-04-M-0531.

WALL, J. S., and J. W. PAulis. 1978. "Corn and Sorghum Grain Proteins." In Advances in Cereal Science and Technology, edited by Y. Pomeranz, 135-219. St Paul: American Association of Cereal Chemists.

Xu, J.-G., Q. P. Hu, X. D. Wang, J. Y. Luo, Y. Liu, and C. R. Tian. 2010. "Changes in the Main Nutrients, Phytochemicals, and Antioxidant Activity in Yellow Corn Grain during Maturation." Journal of Agricultural and Food Chemistry 58 (9): 5751-5756. doi:10.1021/ jf100364k. 